\title{
VERIFICATION OF THE MODEL OF PREDISPOSITION IN TRIATHLON - STRUCTURAL MODEL OF CONFIRMATIVE FACTOR ANALYSIS
}

\author{
Lenka Kováŕová, Karel Kovář
}

Faculty of Physical Education and Sport, Charles University, Prague, Czech Republic

Submitted in August, 2011

BACKGROUND: The triathlon is a combination of three different types of sport - swimming, cycling, and running. Each of these requires different top level predispositions and complex approach to talent selection is a rather difficult process. Attempts to identify assumptions in the triathlon have so far been specific and focused only on some groups of predispositions (physiology, motor tests, and psychology). The latest studies missed the structural approach and were based on determinants of sport performance, theory of sports training and expert assessment.

OBJECTIVE: The aim of our study was to verify the model of predisposition in the short triathlon for talent assessment of young male athletes age 17-20 years.

METHODS: The research sample consisted of 55 top level triathletes - men, who were included in the Government supported sports talent programme in the Czech Republic at the age of 17-20 years. We used a confirmative factor analysis (FA) and Path diagram to verify the model, which allow us to explain mutual relationships among observed variables. For statistical data processing we used a structure equating modeling (SEM) by software Lisrel L88.

RESULTS: The study confirms best structural model for talent selection in triathlon at the age of 17-20 years old men, which composed seventeen indicators (tests) and explained $91 \%$ of all cross-correlations (Goodness of Fit Index /GFI/ 0.91, Root Mean Square Residual /RMSR/ 0.13). Tests for predispositions in triathlons were grouped into five items, three motor predispositions (swimming, cycling and running skills), aerobic and psychological predispositions. Aerobic predispositions showed the highest importance to the assumptions to the general factor $(1.00 ; 0)$. Running predispositions were measured as a very significant factor $(-0.85 ; 0.28)$ which confirms importance of this critical stage of the race. Lower factor weight showed clusters of swimming $(-0.61 ; 0.63)$ and cycling $(0.53 ; 0.72)$ predispositions. The psychological predispositions were found in the lowest effect $(0.36 ; 0.87)$.

CONCLUSIONS: We confirm predispositions and tests for measurement of its level for top level male triathletes in the junior category. The model is in practice today in the Czech Republic, where we used the test standards for dividing Government support of athletic talent.

Keywords: Top level sport, talents assessment, talent selection, endurance in sport, sport diagnostics, structure equating modelling.

\section{INTRODUCTION}

The quality system of talent selection is a primary condition for effective management of sport training. Selection of talents is therefore based on a multi-stage principle and respects developmental stages of an individual. With age and higher performance there appear specific predispositions and skills. Zháněl and Lehnert (2010) in this context, state that the relationship between the level of specific athletic predispositions and sport performance is higher in simple, individual, closed types of sports (e.g. field sports), while in so called open sports (especially team sports) these relationships are very low (Roth \& Willimczik, 1999). Researches in many countries firstly focused on the area of performance predispositions or motor abilities. In the nineties, physiological, psychological and social factors started to be gradually implemented into trends of sport talent identification to various extents. The system of sport talent selection was based on a similar process in most countries. Models of these systems developed processes consisting of three successive steps. Firstly, they identified indicators predicting sport performance then tried to find the tools for differentiating top future athletes from average ones and finally they identified the model of predispositions by means of setting standards of performance in individual performance predictors (Ko et al., 2003).

Apart from the first stage of the selection, when we usually only distinguish children talented for nonspecific sport activity, in other stages it is important to distinguish predispositions of an athlete and the state of fitness, because the individual has already undergone some specific sport training and incorrect assessment may appear (Kováŕ, 1974).

Short triathlon (sometimes also referred to as the Olympic triathlon) combines a $1.5 \mathrm{~km}$ swim, $40 \mathrm{~km}$ cy- 
cling and $10 \mathrm{~km}$ running. The triathlon is a combination of three different types of human locomotion and each of these disciplines requires different predispositions although performance in each of the components is determined by aerobic predispositions.

The problem of identifying the assumptions we see in difficult measurability of performance in a short (drafting) triathlon. Although it is a sport that is evaluated over time, the possibility of drafting in all its parts, however, disables the individual analysis of individual parts and the possibility of comparing the performance of the race is unrealistic (incorrect track length, elevation, weather, the level of the field) (Kováŕová, Jurič, \& Kovár. 2012). Performance in triathlon is rather a latent indicator than a manifest variable and its analysis is even more difficult.

An important note is that the importance of individual components is not equally represented in the overall performance. If we analyze short distance triathlon races in detail, we can see that $15 \%$ of total time is represented by swimming, 55\% by cycling and $29 \%$ by running (Landers, Blanksby, Ackland, \& Monson, 2008). However, it is not a simple sum but one discipline follows another where an individual does not have the chance to succeed against the peloton in the swimming and cycling part of the race despite an athlete's better individual predispositions for these disciplines. On the contrary, the running part as a final discipline often becomes crucial (Fröhlich, Klein, Pieter, Emrich, \& Gießing, 2008). Differences in athletes' times after swimming (and cycling) are minimal; however, the athlete's attempt to stay in touch with other racers requires different effort regarding individual performance. These differences are then fully apparent in the final discipline - running (Peeling, Bishop, \& Landers, 2005). In this sense, even the psychological state of an athlete may be decisive.

\section{METHODOLOGY OF TALENT SELECTION FOR SHORT TRIATHLON}

Since the very beginning of the triathlon, many authors have dealt with the issue of prediction performance (Burke \& Jin, 1996; Sleivert \& Rowlands, 2000; Hue, 2003; Van Schuylenbergh, Vanden Eynde, \& Hespel, 2004; Zemanová \& Kováŕ, 2009), individual solution of issue of talent selection for triathletes in the literature, however, is still missing.

The researchers focused on short-term performance prediction in several fields - anthropometric, morphologic and aerobic predispositions, swimming, running, cycling and psychological. The model of identification of predispositions for future performance in short triathlon thus includes several fields that must be taken into account during its development.
In the field of anthropometrics, we do not register a clear consensus in research focused on this issue due to different anthropometric predispositions, moreover, it appears that triathlon athletes form a specific somatotype (1.96-4.35-3.14) between swimmers, cyclers and middle and long distance runners (Ackland, Blanksby, Landers, \& Smith, 1998). International studies coincide in the parameter of body fat $\%$ as an indicator of future performance (Tittle \& Wutscherk, 1988; Atwater, 1990; Landers, Blanksby, Ackland, \& Smith, 2000); Czech studies agree further on the parameter of extracellular mass and body cell mass (ECM/BCM) - parameter indicative of the qualitative characteristics of skeletal muscle (Talluri, 1998).

However, there is uniformity in the field of aerobic predispositions. Authors suggest $\mathrm{VO}_{2}$ max related to body weight and $\% \mathrm{VO}_{2}$ max at anaerobic threshold (AT) as two primary indicators of performance prediction (Schneider, Lacroix, Atkinson, Troped, \& Pollack, 1990; Butts \& McLean, 1991; Zhou, Robson, King, \& Davie, 1997; Millet, Dreano, \& Bentley, 2003; Suriano \& Bishop, 2010). Some studies also mention the possibility of performance prediction by means of maximum values of pulmonary ventilation.

For future performance prediction by means of motor tests, studies usually suggest laboratory tests for the sake of objectivity of data gained (O'Toole, Douglas, \& Hiller, 1989; Neumann, 1993; Hue, Le Gallais, Chollet, Boussana, \& Préfaut, 2000; Bentley, Millet, Vleck, \& McNaugthon, 2002). The most commonly used is a treadmill or cycling ergometer test up to vita maximum, further speed tests at AT, less on aerobic threshold (Schabort, Killian, St Clair Gibson, Hawley, \& Noakes, 2000; Hue, 2003; Van Schuylenbergh, Vanden Eynde, \& Hespel, 2004). To analyse field motor tests in swimming in junior categories, tests in a swimming pool to assess maximal performance at distances from 400 to $800 \mathrm{~m}$ are used. For the analysis of field motor tests in running, tests at distances from 3 to $5 \mathrm{~km}$ are used.

On the contrary, there is a very different view on the assessment of joint flexibility in the triathlon. It is derived from various flexibility requirements for each discipline. Maximum, even limit flexibility of certain body parts (e.g. hypermobile "swimming" ankle) important for swimming may be contra productive in another discipline (ankle distortion during running). When assessing flexibility predisposition, we should focus primarily on the limit range of motion in the shoulder and ankle joints rather than to assess maximal range of these segments.

In recent decades, relatively much attention has been paid to psychological predispositions. From the research we can deduce that triathlon athletes should have a very low level of nervous liability which enables them to cope with emotionally challenging situations, 
on the contrary, they need a high level of motivation, moral and volitional qualities.

Given the nature of competition and training is proving to be better a tendency to introversion. The one from key areas which to be considered is longterm ability to concentrate attention on performance (Weinberg \& Gould, 2003; Morgan \& Pollock, 1977; Zemanová \& Kovár, 2009). The last study focused on identifying the ability to concentrate attention that we consider crucial. On the basis of the test profile composed of four tests aimed at evaluating concentration of attention (Jirásek's numeric square before and after performance, Numeric rectangle, Bourdon test and Disjunctive reaction time II) they found out that the ability to concentrate attention was statistically significantly higher in triathletes of higher performance levels in all the tests used. Differences were statistically significant in all three diagnostics (Jirásek's tests before performance $\mathrm{t}=-2.92 ; \mathrm{p}=0.005 ; \omega^{2}=0.14$, Jirásek's test after performance $\mathrm{t}=-2.98 ; \mathrm{p}=0.004 ; \omega^{2}=0.12$, Numeric rectangle $\mathrm{t}=2.20 ; \mathrm{p}=0.032 ; \omega^{2}=0.06$, Bourdon test $\mathrm{t}=6.20 ; \mathrm{p}=0.000 ; \omega^{2}=0.40$, Disjunctive test $\mathrm{t}=4.95$; $\left.\mathrm{p}=0.000 ; \omega^{2}=0.29\right)$.

Attempts to find performance predictors in the triathlon have so far been rather intuitive and were based on determinants of sport performance, theory of sports training and expert assessment.

In terms of methodology, statistical processing of the selection of indicators for successful prediction of performance in the triathlon is narrowed to several categories.

Performance prediction is commonly assessed by means of correlation and regression analyses (Butts \& McLean, 1991; Sleivert \& Wenger, 1993; Van Schuylenbergh, Vanden Eynde, \& Hespel, 2004), significance tests (Kohrt, Morgan, Bates, \& Skinner, 1987; Heiden \& Burnett, 2003), analysis of variance (Burke \& Jin, 1996; Landers, Blanksby, Ackland, \& Smith, 2000), and multidimensional linear regresion and regresion equations (Schabort, Killian, St Clair Gibson, Hawley, \& Noakes, 2000; Fröhlich, Klein, Pieter, Emrich, \& Gießing, 2008). Studies have not brought any complex approach to performance prediction yet; our aim was to apply a structural approach to the issue of triathlon talent selection and develop a testing profile predicting performance in the triathlon by means of factor analysis (Blahuš, 1980; Blahuš, 1985; McDonald, 1991). This enables us to explain mutual relationships between the variables observed (individual tests and their relation to concrete performance) and simultaneously reduce the number of variables which simplifies the variable's description. Another advantage is the possibility of developing and verifying structural theory of the examined area, or transformation of the original variable into a more suitable condition.Therefore, we consider the FA in this context to be very appropriate.
Only a few studies indicated an attempt to process the results by means of multidimensional analysis (Lane, Terry, \& Karageorghis, 1995; Landers, Blanksby, Ackland, \& Smith, 2000; Kovářová \& Kovář, 2010), but generally it is used more for sport (Psotta, Blahuš, Cochrane, \& Martin, 2005; Vallerand et al., 2008; Hardy, Roberts, Thomas, \& Murphy, 2010).

\section{METHODS}

The aim of the study was to find and verify a model of predispositions in the short triathlon. First, we created a battery of tests to identify the assumptions and then made their mild reduction. Tests results were subjected to tests of normality and linearity of dependence so that they could be adopted into the test battery; subsequently, a correlation matrix was created (TABLE 2, 3), which was followed by critical analysis of correlation relationships revealing dependences between, as well as inside of, individual areas of the examined performance.

\section{Research sample}

The research sample consisted of 64 triathletes men aged 17-20 included into YSC between years 2005-2008. Due to an absence of results from more than $20 \%$ of tests in nine triathletes, we were forced to exclude these athletes from the sample. Therefore 55 participants were included in the correlation matrix (age $18.9 \pm 1,5$; body height $181.4 \pm 7.0$; body weight $70.5 \pm 7.4 ; \mathrm{VO}_{2} \max \times \mathrm{kg}^{-1} 70.6 \pm 5.0 ; \mathrm{ECM} / \mathrm{BCM}$ $0.76 \pm 0.09 ; \%$ of body fat $9.10 \pm 1.62$ ).

In the case of missing values in some tests, we had to complete them by the mean value of test result of the whole sample. In total, $6 \%$ of missing values were added. Testing was carried out within nationwide control tests of YSC in triathlon, testing of junior national teams and individual Youth Sport Centres in the laboratory of sport motor activities at The Faculty of Physical Education and Sport, Charles University.

The sample included the "whole" population of triathletes in junior category in YSC. Such a selected research sample allowed us to use the method of least squares as we did not have to relate the results to the "general" population. However, this solution has caused some problems, namely that the test profile for performance prediction had been tested on already pre-selected athletes (included in YSC) and thus exists a certain probability of rejecting appropriate tests because of low validity caused by high homogeneity of the sample which had been caused by pre-selection in the form of entrance tests for YSC.

The research was approved by the Ethics Committee of Faculty of Physical Education and Sport, Charles University. Testing was conducted just before the racing season and was spread over two three day blocks. 
Participants were informed in advance of load tests and had adjusted training the last week before the tests. The sequence of tests was identical in all probands.

TABLE 1 presents tests and their characteristics used in diagnostics of predispositions in short triathlon. We used tests selected from the following areas:

1. Anthropometric tests selected on the basis of available studies and our expert assessment [test of body fat measurement by means of bioimpedance method (BIA 2000), test of muscle mass quality (ratio ECM/ BCM)].

2. Aerobic predispositions tests (running test up to vita maxima, cycling test up to vita maxima)

3. Field tests [test of anaerobic threshold in swimming (as an output indicator, we decided for time for $100 \mathrm{~m}$ at the level of AT calculated from $300 \mathrm{~m}$ ) sections, swimming test at $400 \mathrm{~m}$ freestyle, running test at $3 \mathrm{~km}$ ].

4. Psychological tests (Jirásek's numeric square before and after performance, Numeric rectangle, Bourdon test, Disjunctive reaction time II).

5. Tests of flexibility (ranges of movements - angles (degrees) in the individual joints in horizontal or vertical planes) of the following joints [1]: 1. shoulder extension, 2. torso flexion, 3. plantar flexion, 4. dorsal flexion, 5. right arm abduction, 6. external rotation of the right arm, 7. internal rotation of the right arm. As an output variable, a total score T-points was selected. Total score $=\{[(1 .+5 .+6$. +7.) / 4]+2 .+3 .+4.\} / 4$

TABLE 1

Tests and their characteristics used in diagnostics of short triathlon

\begin{tabular}{|c|c|c|c|}
\hline Testing area & Test abbreviation & Test description & Unit \\
\hline \multirow{5}{*}{$\begin{array}{l}\text { Psychological tests } \\
\text { (concentration } \\
\text { of attention) } \\
\text { (Kovářová \& Kovář, 2010) }\end{array}$} & Bourd & Bourdon test, test long term load of attention & $\begin{array}{l}\text { n. of correct } \\
\text { answers }\end{array}$ \\
\hline & Disjunk & $\begin{array}{l}\text { Disjunctive test, test of fitness capacity in ex- } \\
\text { tremely load }\end{array}$ & time $(\mathrm{s})$ \\
\hline & Numeric & $\begin{array}{l}\text { Numeric rectangle test, test selectivity and } \\
\text { distribution }\end{array}$ & $\begin{array}{l}\text { n. of correct } \\
\text { answers }\end{array}$ \\
\hline & Jir_bef & $\begin{array}{l}\text { Jirásek's test before performance, test quality } \\
\text { of concentration of attention }\end{array}$ & time $(s)$ \\
\hline & Jir_after & $\begin{array}{l}\text { Jirásek's test after performance, test quality of } \\
\text { concentration of attention in load }\end{array}$ & time $(\mathrm{s})$ \\
\hline \multirow{3}{*}{$\begin{array}{l}\text { Functional } \\
\text { predispositions tests } \\
\text { (Bunc, Heller, Horčic, } \\
\text { \& Novotný, 1996) }\end{array}$} & Ventil & $\begin{array}{l}\text { Volume breathed in and out per minute at max- } \\
\text { imum performance as protocol by Bunc (1996) }\end{array}$ & $1 \times \min ^{-1}$ \\
\hline & $\mathrm{VO}_{2} \max$ & $\begin{array}{l}\text { Indicator of maximum aerobic performance as } \\
\text { protocol by Bunc (1996) }\end{array}$ & $\mathrm{ml} \times \min ^{-1} \mathrm{~kg}^{-1}$ \\
\hline & $\mathrm{VO}_{2} \mathrm{AT}$ & $\begin{array}{l}\% \text { of aerobic performance at AT as protocol } \\
\text { by Bunc (1996) }\end{array}$ & percentage $(\%)$ \\
\hline \multirow{9}{*}{$\begin{array}{l}\text { Swimming } \\
\text { predispositions tests } \\
\text { (Horčic, 2004) }\end{array}$} & S_400m & $400 \mathrm{~m}$ free style test & time $(\mathrm{s})$ \\
\hline & S_AT & Time for $100 \mathrm{~m}$ at AT & time $(\mathrm{s})$ \\
\hline & \multirow{7}{*}{$\begin{array}{l}\text { Flexibility specific tests of flexibility } \\
\text { Total score }= \\
{[[(1 .+5 .+6 .+7 .) / 4]+2 .+3 .+4 .\} / 4} \\
\text { Total score converted to T-points was } \\
\text { chosen as an output variable }\end{array}$} & 1. Arms extension & \multirow[t]{7}{*}{$\mathrm{T}$ - points } \\
\hline & & 2. Trunk flexion & \\
\hline & & 3. Plantar flexion & \\
\hline & & 4. Dorsal flexion & \\
\hline & & 5. Right arm abduction & \\
\hline & & 6. External rotation of the right arm & \\
\hline & & 7. Internal rotation of the right arm & \\
\hline \multirow{3}{*}{$\begin{array}{l}\text { Running } \\
\text { predispositions tests } \\
\text { (Bunc, Heller, Horčic, } \\
\text { \& Novotný, 1996) }\end{array}$} & R_3 km & $3 \mathrm{~km}$ running test & time \\
\hline & R_AT & Time for $1 \mathrm{~km}$ at AT & time $(\mathrm{s})$ \\
\hline & Treadmill & $\begin{array}{l}\text { Maximum speed reached at the end of the test } \\
\text { protocol by Bunc (1996) }\end{array}$ & $\mathrm{km} / \mathrm{h}$ \\
\hline \multirow{3}{*}{$\begin{array}{l}\text { Cycling } \\
\text { predispositions tests } \\
\text { (Bunc, Heller, Horčic, } \\
\text { \& Novotný, 1996) }\end{array}$} & B_Wmax & $\begin{array}{l}\text { Maximum performance reached at the end of } \\
\text { test as protocol by Bunc (1996) }\end{array}$ & $\mathrm{W} \times \mathrm{kg}^{-1}$ \\
\hline & B_AT & Performance at AT as protocol by Bunc (1996) & $\mathrm{W} \times \mathrm{kg}^{-1}$ \\
\hline & $\mathrm{ECM} / \mathrm{BCM}$ & $\begin{array}{l}\text { Measured by bioimpedance method; test quali- } \\
\text { tative characteristics of skeletal muscle }\end{array}$ & none \\
\hline
\end{tabular}


The testing system was composed of seventeen indicators covering all areas scoring performance prediction (TABLE 1, Fig. 1). In the initial correlation matrix were included tests identifying anaerobic predispositions (such as a swimming test - 10 swim freestyle stroke max. effort and cycling test Wingate test $-30 \mathrm{~s}$ ). Their mutual correlation with other indicators, however, were very low and even found a low negative relationship with test evaluation of aerobic conditions (eg, $\mathrm{r}=-0.21$ between performance on the $400 \mathrm{~m}$ swim and performance in the test 10 swim freestyle stroke max effort or $r=-0.14$ between the performance at AT and power output in the Wingate test) and again there was a phenomenon that the best triathletes achieved the lowest performance in the anaerobic tests. The final matrix we therefore did not include these tests.

For verification, we used FA and Path diagram. To process the data gained, we used confirmatory factor analysis - least squares method (UL). For statistical data processing we used Lisrel L88 software.

Confirmative factor analysis is based on testing hypotheses related to the fact whether the initial correlation matrix can be represented by the correlation matrix derived on the basis of the assumption that the measured variables were created as a specific linear combination of factors. Confirmative factor analysis therefore, instead of extraction and rotation of optional factors, tests a specific hypothesis about the load matrix (Hendl, 2006).

In the structural model of confirmative factor analysis, several important indicators are being evaluated. Factor loading (X) of empirical indicator (manifest variable) is assessed in relation to its latent factor (construct) and simultaneously its uniqueness (unexplainable part) (Y). The values of factor loading and uniqueness are writing then $(\mathrm{X}, \mathrm{Y})$. Generally, we can state that the model is better if factor loadings are as high as possible while uniqueness of indicators as low as possible. This statement is limited, of course, in terms of the theory of factor analysis, namely that factor analysis and uniqueness range in the interval of $\langle 0 ; 1\rangle$, so that their values cannot acquire negative numbers. Should the factor loading be equal to 1 and uniqueness to 0 , manifest variable (empirical indicator) is equal to the latent variable (factor) and thus is also a construct itself (Blahuš, 1985).

Furthermore, we assess indicators of the overall fit model. For this purpose the Lisrel programme provides the indicator Goodness of Fit Index (GFI). The result is an interval of $\langle 0 ; 1\rangle$. If we multiply this value by 100 , we obtain a percentage of the explained part of the model, namely information about what percentage of the model is explained. Thus we can state that the more the value of indicator approaches $1(100 \%)$, the better hypothesis was tested. Dillon and Goldstein (1984) consider a value of 0.90 as a level of very good accuracy.
Finally, it is also necessary to assess the indicators of unexplained correlations, or total mean of unexplained correlations or deviations of the initial matrix from the correlation matrix derived on the basis of our hypothesis. Programmes offer the Root mean squared residual (RMSR) index for this assessment. This indicator ranges between $\langle 0 ; 1\rangle$, when the lowest value, the lowest total unexplained correlation in the model and thus the best for our hypothesis. Chau (1997) suggests a border of very good agreements the value of 0.10 . The Lisrel programme requires values higher than 0.97 for confirmation of excellent accuracy while RMSR lower than 0.061 .

\section{RESULTS}

The results of the correlation matrix (TABLE 1,2) show a high correlation between all the tests measuring concentration of attention, their relationship to other tests is low. On the contrary, a high correlation is found in test \% fat to all the motor tests. Flexibility tests have a high correlation only to motor tests in swimming. The value of $\mathrm{ECM} / \mathrm{BCM}$ seems high correlation to test \% fat, and also to the results of motor tests in cycling and aerobic predisposition tests. These parameters have therefore decided to further analyze using Path diagram. The overall model of predispositions is depicted in Fig. 1. TABLE 4 presents indicators of overall fit model and their value.

We proposed an acceptable model of predispositions for triathlon, the correlation matrix of which is explained by $91 \%$ and Root Mean Square Residual is 0.13 (TABLE 4). The maximum possible factor weight, with regards to the general factor (predispositions for triathlon), was found in aerobic predispositions $(1.00 ; 0)$, a very significant factor weight was measured in running predispositions $(-0.85 ; 0.28)$, followed by swimming $(-0.61 ; 0.63)$ and cycling predispositions $(0.53 ; 0.72)$. The lowest effect was found in psychological predispositions $(0.36 ; 0.87)$.

Tests $\mathrm{VO}_{2}$ max and Ventil best explained aerobic predispositions $(0.81 ; 0.35)$. Test $R_{-} A T$, i. e. time for running at $1 \mathrm{~km}$ by speed at AT best explained running predispositions $(0.95 ; 0.10)$ while in Treadmill test, i.e. maximum speed achieved at the end of the test on the treadmill $(-0.93 ; 0.13)$, the values were slightly lower. The most suitable test for identification of swimming predispositions appears to be S_AT, i. e. time for $100 \mathrm{~m}$ at AT $(0.94 ; 0.11)$. In terms of cycling predispositions, there were similar results in both tests B_Wmax $(0.79$; $0.37)$ and B_AT $(0.78 ; 0.39)$. Test Jir_after (Jirásek's test after performance) showed the best results for the psychological predispositions $(-1.00 ; 0.14)$. 
TABLE 2

Correlation matrix (part 1)

\begin{tabular}{|l|c|c|c|c|c|c|c|c|c|}
\hline & Bourd & Disjunk & Numeric & Jir_bef & Jir_after & Ventil & VO_max $_{2}$ & VO $_{2}$ AT & S_400 m \\
\hline Bourd & 1 & & & & & & & & \\
\hline Disjunk & 0.63 & 1 & & & & & & & \\
\hline Numeric & 0.51 & 0.57 & 1 & & & & & & \\
\hline Jir_bef & -0.53 & -0.60 & -0.68 & 1 & & & & & \\
\hline Jir_after & -0.67 & -0.69 & -0.79 & 0.84 & 1 & & & & \\
\hline Ventil & 0.10 & 0.01 & -0.01 & -0.05 & -0.11 & 1 & & & \\
\hline VO_max & 0.33 & 0.03 & 0.27 & -0.32 & -0.41 & -0.69 & 1 & & \\
\hline VO' $\mathbf{A T}$ & 0.36 & 0.07 & 0.21 & -0.27 & -0.34 & -0.77 & 0.39 & 1 & \\
\hline S_400 $^{2}$ & -0.10 & -0.24 & 0.08 & 0.12 & 0.21 & -0.14 & -0.53 & -0.06 & 1 \\
\hline
\end{tabular}

TABLE 3

Correlation matrix (part 2)

\begin{tabular}{|l|c|c|c|c|c|c|c|c|}
\hline & S_AT & Flexibility & R_3 km & R_AT & Treadmill & B_Wmax & B_AT & ECM/BCM \\
\hline S_AT & 1 & & & & & & & \\
\hline Flexibility & -0.61 & 1 & & & & & & \\
\hline R_3 km & 0.32 & -0.15 & 1 & & & & & \\
\hline R_AT & 0.43 & -0.24 & 0.70 & 1 & & & & \\
\hline Treadmill & -0.36 & 0.21 & -0.63 & -0.88 & 1 & & & \\
\hline B_Wmax & -0.29 & 0.08 & -0.13 & -0.06 & 0.31 & 1 & & \\
\hline B_AT & -0.38 & 0.11 & -0.43 & -0.35 & 0.21 & 0.53 & 1 & \\
\hline ECM/BCM & 0.27 & -0.05 & 0.31 & 0.22 & 0.24 & -0.57 & -0.42 & 1 \\
\hline
\end{tabular}

TABLE 4

Indicators of overall model fit

\begin{tabular}{|l|l|}
\hline Goodness of Fit Index (GFI) & 0.91 \\
\hline Root Mean Square Residual (RMSEA) & 0.13 \\
\hline
\end{tabular}

The remaining question is where to include a test of $\%$ of body fat (in the general population, indicator $\%$ of body fat is a good predictor of endurance predispositions but in a very homogenous group of trained triathletes with very similar values it is not possible to use it as a predictor). In this case, several possible solutions exist.

1. Percentage of body fat test will explain only some of swimming, running or cycling factors.

2. Percentage of body fat test will, together with ECM/ BCM test, create a separate cluster of "anthropometric predispositions".

3. Percentage of body fat test will explain all factors.

Firstly, we will create a model without the indicator of $\%$ of body fat. Thereafter, we will anticipate one general factor, five subordinated latent variables and 17 indicators. Results of such a proposed model are as follows.
In the second solution (create a separate cluster of "anthropometric predispositions") we achieved again an acceptable model of predispositions for triathlon, in which GFI was lower than in the first variant and the correlation matrix was explained from $85 \%$ and Root Mean Square Residual (RMSR) 0.17. With respect to the maximum value of 1 in the discussed indicator of \% of body fat we rejected variant no. 2 as the model, which we do not consider as more appropriate than no. 1 and decided to proceed to another step (variant no. 3). Indicator of \% of body fat together with indicators ECM/ $\mathrm{BCM}$ and joint mobility were transferred to another category, which was possible due to the Lisrel88 programme. The structural model thus changed into a Path diagram (Fig. 2), which revealed regression coefficients (in this case, numbers placed near to direction arrows between predicates and latent variables do not represent 
Fig. 1

Overall model of predispositions for triathlon (latent factors model)

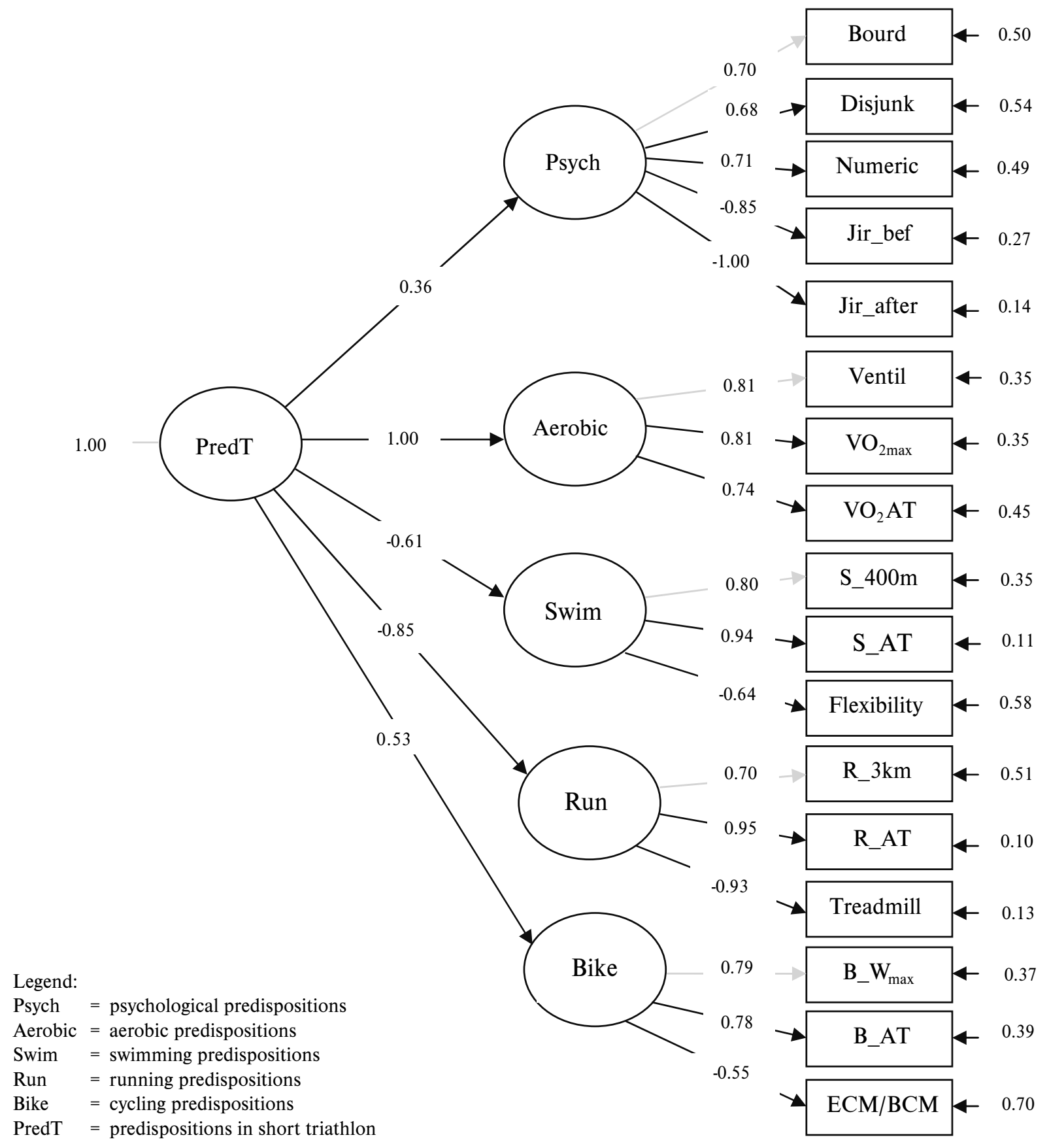

factor loadings but regression coefficients) of these variables and provided information on explained variances in individual dependent and independent variables (TABLE 5).

As we can see form TABLE 5 and Fig. 2, indicator of $\%$ of body fat was an excellent predictor of all factors in our model (swimming predispositions $\mathrm{R}^{2}=0.57$; cycling predispositions $\mathrm{R}^{2}=0.62$; running predispositions $\mathrm{R}^{2}=0.78$ ). Ratio ECM/BCM, or parameter assessing quality of muscle mass, had the highest regression coefficient $\left(\mathrm{R}^{2}=0.68\right)$ to cycling predispositions; in contrast, it explained relationships to swimming and running predispositions to a very small extent. Indicators of joint mobility best explained swimming predispositions $\left(\mathrm{R}^{2}=0.69\right)$. Surprisingly low regression was found in relationships between psychological predispositions and all "motor" factors (swimming, cycling and running). 
Fig. 2

Path diagram

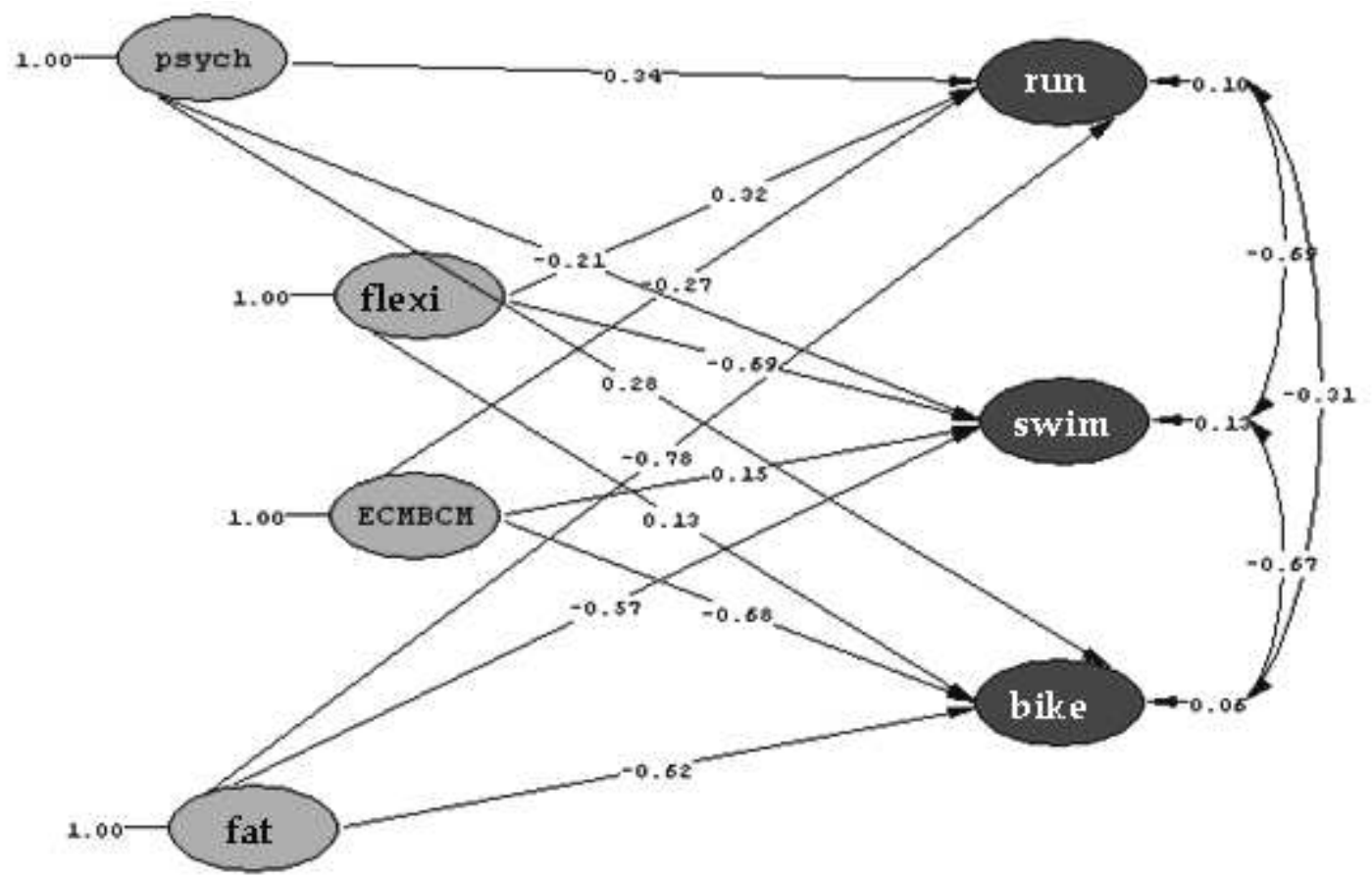

TABLE 5

Indicators of Path diagram

\begin{tabular}{|l|c|c|c|}
\hline Predicate & Swimming predispositions & Cycling predispositions & Running predispositions \\
\hline Psychological predispositions & 0.21 & 0.28 & 0.34 \\
\hline Elexibility & 0.69 & 0.13 & 0.32 \\
\hline ECM/BCM & 0.15 & 0.68 & 0.27 \\
\hline \% body fat & 0.57 & 0.62 & 0.78 \\
\hline Regression residuum & 0.13 & 0.05 & 0.10 \\
\hline
\end{tabular}

\section{DISCUSSION}

The model of test battery verification is composed of seventeen indicators that could not be reduced more. Some of the tests identify the level of fitness as well as other genetic predispositions. This allows us to separate these areas to some extent, to determine the level of fitness and recommend further possibilities for improvement of triathletes examined and estimate their performance limit.

The correlation matrix was explained by a model of $91 \%$, which can be considered acceptable (Dillon \& Goldstein, 1984; Chau, 1997). The question remains, what might contribute to the increase the GFI and whether it actually did not test anaerobic assumptions? There is also the question of the aerobic assumptions related to motor conditions for swimming, cycling and running so that it would form a separate cluster. We did not confirm this hypothesis, and this model appeared to be less fit (GFI 0.82, RMSR 0.19). However, the results confirm previous studies that both reported aerobic assumptions as a keystone the performance prediction and selection of talent.

Maximum possible factor loading to the general factor was represented in aerobic predispositions $(1.00 ; 0)$. These are the most important in terms of identification of predispositions for future performance in short triathlon. At this moment, the interpretation offered is to substitute all tests by only those aerobic ones and to predict performance in triathlon only by means of these predispositions. However, this is in contrast to another finding, namely that aerobic predispositions are indeed necessary, but not the one and only sufficient condition for selection of talented athletes. 
At this phase, the interpretation to replace all tests by those aerobic appears and thus to predict the performance in triathlon only by means of these predispositions, which, as mentioned above, is the most usual approach (regression analysis). However, this "simplification" is in contrast to another conclusion, i. e. that aerobic predispositions are not only essential, but also the only one sufficient condition for talented athletes' selection.

The second highest factor loading was detected in running predispositions $(-0.85 ; 0.28)$, followed by swimming $(-0.61 ; 0.63)$ and cycling predispositions $(0.53$; 0.72 ). This finding is in accordance with earlier studies (Fröhlich, Klein, Pieter, Emrich, \& Gießing, 2008), which also pointed out the importance of the running part in triathlon. Analyses of score sheets from races indicate that an excellent usually runner wins although he can be a worse swimmer or cyclist. The course of competition can erase performance differences from swimming and cycling parts but running performance, as the last part of triathlon, has the ultimate impact on the final result. High factor loading of running predispositions is probably related to the fact that running is the final and decisive discipline in triathlon. Lower factor loadings of cycling predispositions correspond to the current concept of the race when by means of drafting it is possible to reduce the resistance while riding behind another competitor and thus to save energy. Technical and tactical components of the cycling part may thus significantly reduce differences in competitors' performance. On the contrary, low swimming performance usually signifies no hope for a top final result and probably this is the reason for higher factor loading of swimming predispositions. This conclusion does not correspond with the results (Kovářová \& Kovár̆, 2010) and it seems that the influence of swimming performance is more important than the corresponding analysis of its own parts. This will probably be due to so-called drafting.

The lowest value was represented by psychological predispositions $(0.36 ; 0.87)$. This did not confirm the results of a previous study (Zemanová \& Kováŕ, 2009) that psychological predispositions will be essential in the model of predispositions in triathlon. The reason for the very low factor weight of this latent variable in the overall model could be the lower validity of psychological tests than, for instance, aerobic tests, which led to lower (insignificant) correlation and overall factor weight in the model was thus lower, as well.

Another reason could be a higher heterogeneity of the sample or the wrong choice of indicators. When verifying the partial model, we used only tests of concentration of attention which could reduce the problem of psychological predispositions significantly and misleadingly. We assume that, with regards to the character of motor predispositions, it would be more appropriate to include some tests of moral and volitional characteristics and motivation into the model. On the other hand, the problem could be the assurance of measurements quality in such a test battery. However, we do not exclude general overestimation of psychological predispositions in endurance sports.

Another problem, which we noticed in the application of factor analysis in a specific area of elite sport, is the generalization which is connected with modelling. Is it even possible to generalize something as specific as what the future estimation of predispositions for extreme endurance load is? On the other hand, each statistical method is based on some generalization and the method of factor analysis for the area of modelling predispositions is directly addressed to this problem. However, a negative fact is that this method has not been used so far in the area of identification of predispositions for future sport performance in the triathlon and therefore we can not compare the results of our study with similar ones.

In cases when we test battery for performance prediction in already pre-selected athletes (e.g. those included in YSC), there is still a certain probability of rejecting the suitable test because of the low validity caused by high homogeneity of the sample which is the result of pre-selection in the form of admission tests to YSC. Seemingly low test validity in the selected candidates may lead to deceptive rejection of a good admission test (Fajfer, 2000).

In an attempt to "manipulate" with an indicator of \% of body fat and to add it to some of the latent factors, the model fit did not improve; in some cases, negative values in test uniqueness occurred or uniqueness of test of $\%$ body fat reached a value over one. An interesting component in our model was the indicator of percentage of body fat. This parameter explained running predispositions to a large extent (78\%), as well as cycling $(62 \%)$ and swimming predispositions (57\%). The lower percentage in swimming can be explained by "ambiguity" of the somatotype suitable for swimming. Good swimmers can have a higher proportion of body fat; on the other hand, excellent swimmers are also among ectomorphs with long segments of lower and upper extremities. The arising question is whether a test of the \% of body fat is no more a mediator or moderator (Baron \& Kenny, 1986) than a manifest (dependent) variable and whether it does not enter into other relationships. Our result was in accordance with already mentioned research (Landers, Blanksby, Ackland, \& Smith, 2000), in which the regression coefficient was calculated from times from races in individual disciplines, not from the path diagram. 


\section{CONCLUSIONS}

We created a structural model of predispositions for short triathlon that explained $91 \%$ of all cross-correlations (Goodness of Fit Index /GFI/ 0.91, Root Mean Square Residual /RMSR/ 0.13).

On the basis of confirmatory factor analysis, predispositions of triathlon were divided into five groups as for the fields of swimming, cycling and running (according to individual disciplines) and for the area of aerobic and psychological predispositions. We recommend applying these tests for talent selection in the triathlon for the age group of 17-19 years.

The maximum possible factor weight, with regards to the general factor, was found in aerobic predispositions $(1.00 ; 0)$, a very significant factor weight was measured in running predispositions $(-0.85 ; 0.28)$, followed by swimming $(-0.61 ; 0.63)$ and cycling predispositions $(0.53 ; 0.72)$. The lowest effect was found in psychological predispositions $(0.36 ; 0.87)$.

The ratio of ECM/BCM predicted most precisely predispositions for the cycling part $\left(\mathrm{R}^{2}=0.68\right)$, considerably worse running predispositions $\left(\mathrm{R}^{2}=0.27\right)$ and even less swimming predispositions $\left(\mathrm{R}^{2}=0.15\right)$.

The value of percentage of body fat predicted most accurately predispositions for running part of triathlon $\left(R^{2}=0.78\right)$, less accurately for cycling part $\left(R^{2}=0.62\right)$ and the least predispositions for swimming $\left(\mathrm{R}^{2}=0.57\right)$, however, all values measured are relatively high.

Tests of specific joint mobility best predict swimming predispositions $\left(R^{2}=0.69\right)$, significantly worse running predispositions $\left(\mathrm{R}^{2}=0.32\right)$ and the worst cycling predispositions $\left(\mathrm{R}^{2}=0.13\right)$.

This model is currently used as a tool for the evaluation of the conditions for entry into the junior and U23 triathlon team. Its financial requirements are due to small representation of the budget. The possibility to assess the level of assumptions and to correctly diversify financial resources of competitors is more economical. For the selection of talent in the younger categories, we tend to reduce some tests.

\section{ACKNOWLEDGEMENT}

This research was supported by the grant MSM 0021620864 and GA UK 258159.

\section{REFERENCES}

Atwater, A. E. (1990). Gender differences in running. In P. R. Cavanagh (Ed.), Biomechanics of Distance Running (pp. 321-362). Champaign, IL: Human Kinetics Publishers.
Ackland, T. R., Blanksby, B. A., Landers, G., \& Smith, D. (1998). Anthropometric profiles of elite triathletes. Journal of Science and Medicine in Sports, 1, 53-56.

Baron, R. M., \& Kenny, D. A. (1986). The moderator mediator variable distinction in social psychological research: Conceptual, strategic, and statistical considerations. Journal of Personality and Social Psychology, 51(6), 1173-1182.

Bentley, D. J., Millet, G. P., Vleck, V. E., \& McNaugthon, L. R. (2002). Specific aspects of contemporary triathlon: Implications for physiological analysis and performance. Sports Medicine, 32(6), 345-359.

Blahuš, P. (1985). Faktorová analýza a její zobecnění. Praha: SNTL.

Blahuš, P. (1980). Základy modelů latentnich proměnných včetně faktorové analýzy. Praha: Univerzita Karlova.

Bunc, V., Heller, J., Horčic, J., \& Novotný, J. (1996). Physiological profile of best Czech male and female young triathletes. Journal of Sports Medicine and Physical Fitness, 36, 265-270.

Burke, S. T., \& Jin, P. (1996). Predicting performance from a triathlon event. Journal of Sports Behavior, 19(4), 272-287.

Butts, N. K., \& McLean, D. (1991). Correlations between $\mathrm{VO}_{2}$ max and performance times of recreational triathletes. Journal of Sports Medicine and Physical Fitness, 31, 339-344.

Dillon, W. R., \& Goldstein, M. (1984). Multivariate analysis: Methods and applications. New York: Wiley.

Fajfer, Z. (2000). Predikce spotovního výkonu - zkreslení validity počátečním přijímáním lepších uchazečů. Česká kinantropologie, 4(1), 99-103.

Fröhlich, M., Klein, M., Pieter, A., Emrich, E., \& Gießing, J. (2008). Consequences of the three disciplines on the overall result in Olympic distance triathlon. International Journal of Sports Science and Engineering, 2(4), 204-210.

Hardy, L., Roberts, R., Thomas, P. R., \& Murphy, S. M. (2010). Test of Performance Strategies (TOPS): Instrument refinement using confirmatory factor analysis. Psychology of Sport and Exercise, 11(1), 27-35.

Heiden, T., \& Burnett, A. (2003). The effect of cycling on muscle activation in the running leg of an Olympic distance triathlon. Sports Biomechanics, 2(1), 35-49.

Hendl, J. (2006). Přehled statistických metod zpracování dat. Praha: Portál.

Hue, O. (2003). Prediction of drafted-triathlon race time from submaximal laboratory testing in elite triathletes. Canadian Journal of Applied Physiology, 28(4), 547-560.

Hue, O., Le Gallais, D., Chollet, D., Boussana, A., \& Préfaut, C. (2000). Ventilatory threshold and maximal oxygen uptake in present triathletes. $\mathrm{Ca}$ nadian Journal of Applied Physiology, 25, 102-113. 
Chau, P. Y. (1997). Reexamining a model for evaluating information center success using a structural equation modeling approach. Decision Sciences, 28(2), 309-334.

Ko, B. G., Gu, H. M., Park, D. H., Back, J. H., Yun, S. W., Lee, M. C., \& Shin, S. Y. (2003). The construction of sports talent identification model. International Journal of Applied Sports Sciences, 15(2), 64-84.

Kohrt, W., Morgan, D., Bates, B., \& Skinner, J. S. (1987). Physiological response of triathletes to maximal swimming, cycling and running. Medicine and Science in Sports and Exercise, 19, 51-55.

Kovář, R. (1974). Př́spěvek ke studiu genetické podminěnosti lidské motoriky. Praha: Univerzita Karlova.

Kovářová, L., \& Kovář, K. (2010). Concentration of attention as a predisposition of performance in junior categories in endurance sports. Acta Universitatis Palackianae Olomucensis. Gymnica, 40(1), 23-33.

Kovářová, L., \& Kovář, K. (2010). Vliv použití triatlonového neoprenového obleku na míru rozptýlenosti seskupení startovního pole v plavecké části triatlonu v závodech světového poháru. Česká kinantropologie, 14(3), 75-86.

Kovářová, L., Jurič, M., \& Kovář, K. (2012). Analýza výkonu v triatlonu. Studia Sportiva, 6(1), 83-91.

Landers, G. J., Blanksby, B. A., Ackland, T. R., \& Monson, R. (2008). Swimming position and its influence on triathlon outcome. International Journal of Exercise Scientice, 1(3), 96-105.

Landers, G. J., Blanksby, B. A., Ackland, T. R., \& Smith, D. (2000). Morphology and performance of world championship triathletes. Annals of Human Biology, 27(4), 387-400.

Lane, A. M., Terry, P. C., \& Karageorghis, C. I. (1995). Path analysis examinig relationship among antecedents of anxiety, multidimensional stae anxiety, and traithlon performance. Perceptual and Motor Skills, 81(3/2), 1255-1266.

McDonald, R. P. (1991). Faktorová analýza a príbuzné metody v psychologii. Praha: Academia.

Millet, G. P., Dreano, P., \& Bentley, D. J. (2003). Physiological characteristics of elite short and long distance triathletes. European Journal of Alied Physiology, 88, 427-430.

Morgan, W. P., \& Pollock, M. C. (1977). Psychological characterization of the elite distance runner. Annals of the New York Academy of Science, 301, 382-405.

Neumann, G. (1993). Zum zeitlichen Ablauf der Anpassung beim Ausdauertraining. Leistungssport, 23(5), 9-14.

Niedeffer, R. M. (1993). Concentration and attention control training. In J. Williams (Ed.), Alied sport psychology (pp. 243-262). Palo Alto: Mayfield.

O’Toole, M. L., Douglas, P. S., \& Hiller, W. B. (1989). Lactat, oxygen uptake and cycling performance in triathletes. International Journal of Sports Medicine, 10, 413-418.

Peeling, P. D., Bishop, D. J., \& Landers, G. J. (2005). Effect of swimming intensity on subsequent cycling and overall triathlon performance. British Journal of Sports Medicine, 39, 960-964.

Psotta, R., Blahuš, P., Cochrane D, J., \& Martin A, J. (2005). The assessment of an intermittent high intensity running test. Journal of Sports Medicine and Physical Fitness, 45(3), 248-256.

Roth, K., \& Willimczik, K. (1999). Bewegungswissenschaft. Reinbek bei Hamburg: Rowohl.

Schabort, E. J., Killian, S. C., St. Clair Gibson, A., Hawley, J. A., \& Noakes, T. D. (2000). Prediction of triathlon race time from laboratory testing in national triathletes. Medicine and Science in Sports and Exercise, 32, 844-849.

Schneider, D. A., Lacroix, K. A., Atkinson, G. R., Troped, P. J., \& Pollack, J. (1990). Ventilatory threshold and maximal oxygen uptake during cycling and runnig in triathletes. Medicine and Science in Sports and Exercise, 22, 257-264.

Sleivert, G., G., \& Rowlands, D. S. (2000). Physical and physiological factors associated with success in triathlon. Sports Medicine, 22, 8-18.

Sleivert, G. G., \& Wenger, H. A. (1993). Physiological predictors of short-course triathlon performance. Medicine and Science in Sports and Exercise, 25, 871-876.

Suriano, R., \& Bishop, D. (2010). Physiological attributes of triathletes. Journal of Science and Medicine in Sport, 13(3), 340-347.

Talluri, T. (1998). Qualitative human body composition analysis assessed with bioelectrical impedance. Collegium Antropologicum, 22(2), 427-432.

Tittle, K., \& Wutscherk, H. (1988). Anatomical and antropometric fundamentals of endurance. In R. J. Shepard \& P. O. Astrand (Eds.), Endurance in Sport, the Encyclopedia of Sports Medicine (pp. 35-45). Oxford: Blackwell Scientific Publication.

Vallerand, R. J., Mageau, G. A., Elliot, A. J., Dumais, A., Demers, M. A., \& Rousseau, F. (2008). Passion and performance attainment in sport. Psychology of Sport and Exercise, 9(3), 373-392.

Van Schuylenbergh, R., Vanden Eynde, B., \& Hespel, P. (2004). Prediction of sprint triathlon performance from laboratory tests. European Journal of Alied Physiology, 91, 94-99.

Weinberg, R. S., \& Gould, D. (2003). Foundations of sport and exercise psychology. Champaing, IL: Human Kinetics.

Zemanová, L., \& Kovář, K. (2009). Koncentrace pozornosti jako předpoklad výkonu v triatlonu. Česká kinantropologie, 13(3), 75-85.

Zhou, S., Robson, J., King, M. J., \& Davie, A. J. (1997). Correlations between short course triathlon perfor- 
mance and physiological variables determined in laboratory cycle and treadmill tests. Journal of Sports Medicine and Physical Fitness, 37, 122-130.

\section{OVĚ̌̌ENÍ MODELU IDENTIFIKACE PŘEDPOKLADŮ V TRIATLONU - STRUKTURÁLNÍ MODEL KONFIRMAČNÍ FAKTOROVÉ ANALÝZY}

(Souhrn anglického textu)

VÝCHODISKA: Triatlon je kombinací tři odlišných sportů - plavání, cyklistiky a běhu. Každý z nich vyžaduje odlišné předpoklady, a komplexní přístup $\mathrm{k}$ výběru talentu je tak poměrně složitý proces. Pokusy identifikovat předpoklady $\mathrm{v}$ triatlonu byly doposud ojedinělé a zaměřovaly se pouze na některé oblasti (funkční předpoklady, motorické testy, psychologie). Nejnovější studie opomíjejí strukturální přístup a vycházejí zpravidla $\mathrm{z}$ determinant sportovního výkonu, teorie sportovního tréninku a expertního posouzení.

CÍLE: Cílem naší práce bylo ověřit model předpokladů v krátkém triatlonu pro kategorii mužů (juniorů) ve věku 17-20 let.

METODIKA: Výzkumný soubor byl tvořen 55 triatlonisty - muži zařazenými do sportovních center mládeže v České republice v triatlonu ve věku 17-20 let. Pro ověřní modelu jsme použili konfirmační faktorovou analýzu a Path diagram, které umožňují vysvětlit vzájemnou souvislost mezi pozorovanými jevy. Pro zpracování dat jsme použili metody strukturálního modelování (SEM) a software Lisrel L88.

VÝSLEDKY: Studie ověřila strukturální model předpokladů pro triatlon pro kategorii mužů ve věku 17-20 let, který se skládá ze sedmnácti indikátorů (testů) a vysvětluje $91 \%$ všech vzájemných korelací (Goodness of Fit Index /GFI/ 0.91, Root Mean Square Residual /RMSEA/ 0.13). Testy předpokladů pro triatlon byly rozděleny do pěti skupin, tři pro oblast motorických předpokladů (plavání, cyklistika, běh), dále předpoklady funkční a psychické. Maximální možnou faktorovou váhu ke generálnímu faktoru představovaly funkční předpoklady $(1,00 ; 0)$. Velmi významnou váhu pak měly běžecké předpoklady $(-0,85 ; 0,28)$ a potvrzuje se, že běžecké dispozice mají v rozhodujících fázích závodu nejvyšší prioritu. Nižší faktorovou váhu představovaly předpoklady pro plavání $(-0,61 ; 0,63)$ a cyklistiku $(0,53 ; 0,72)$. Nejnižší váha byla zjištěna u psychických předpokladů $(0,36 ; 0,87)$.

ZÁVĚRY: Ověřili jsme model předpokladů a baterii testů pro vrcholové triatlonisty juniorské kategorie. Model je v současnosti využíván v České republice, kde slouží pro výběr sportovních talentů v systému SCM.

Klíčová slova: vrcholový sport, posuzování talentu, výběr talentů, vytrvalost, diagnostika, strukturální modelování.
Mgr. Lenka Kovářová, Ph.D., MBA

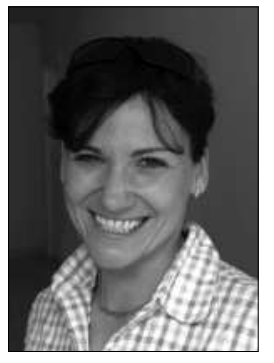

Charles University
Faculty of Physical Education and Sport
José Martího 31
16252 Praha 6
Czech Republic

Education and previous work experience

2008-2010 - Czech Management Institute Prague (Escuela Superior de Marketing y Administración).

2006-2011 - Faculty of Physical Education and Sport, Charles University (doctoral study, specialization - Kinanthropology).

1998-2005 - one branch study of physical education with specialization to triathlon and endurance multicontests (Faculty of Physical Education and Sport, Charles University).

Work experience

2009 - Academic employee of Charles University, Faculty of Physical Education and Sport, Laboratory of Sport Motor Activities.

1998-2008 - sport instructor (Sport Department of the Ministry of the Interior).

Sport success

Academic World Champion in triathlon.

Participant in OG (2004 Athens, Greece; 2008 Peking, China).

Other activities

Assistant of the main coach of senior national team in modern pentathlon. Sport Director of the Czech triathlon association. Member of the Presidium of the Fair Play Club of the Czech Olympic Committee.

Others

Prize of Josef Hlavka Foundation for the best students and graduates of universities of Prague, Brno Technical University, and young researchers of the Czech Academy of Sciences.

\section{First-line publications}

Kovářová, L. (2012). K identifikaci predpokladi̊ v triatlonu. Praha: Karolinum.

Kovářová, L., \& Kovář, K. (2010). Concentration of attention as a predisposition of performance in junior categories in endurance sports. Acta Universitatis Palackianae Olomucensis. Gymnica, 40(1), 23-33.

Kovářová, L., \& Kováŕ, K. (2011). Comparison of heart rate and the lactate level of individual anaerobic threshold in swimming, cycling and running in the triathlon. Antpropomotoryka, 21(56), 57-65.

Kovářová, L., Soukup, P., \& Kovář, K. (2012). Vliv alkoholu na změny srdeční frekvence v běhu při vytrvalostní zátěži na úrovni anaerobního prahu. Česká kinantropologie, 16(4), 111-123. 